\title{
Working in family firms
}

\section{Family firms offer higher job security but lower wages than other firms}

Keywords: family firms, wages, job security, working conditions, paternalism

\section{ELEVATOR PITCH}

Family firms are ubiquitous in most countries. The differences in objectives, governance, and management styles between those firms and their non-family counterparts have several implications for the workforce, which scholars have only recently started to investigate. Family firms offer greater job security, employ different management practices, have a comparative advantage to avoid conflicts when employment relations are more hostile, and provide insurance to workers through implicit contracts when labor market regulation is limited. But all this also comes at a cost.

\section{KEY FINDINGS}

\section{Pros}

(- Family firms offer higher job security because they do not adjust employment levels to economic shocks as much as non-family firms.

๑ Labor conflicts are less intense and less frequent in family firms.

(- Family firms can act as a substitute to publicly provided unemployment insurance or employment guarantees by insuring workers against economic shocks.

(- Absenteeism is lower in family firms, possibly reflecting higher effort levels.

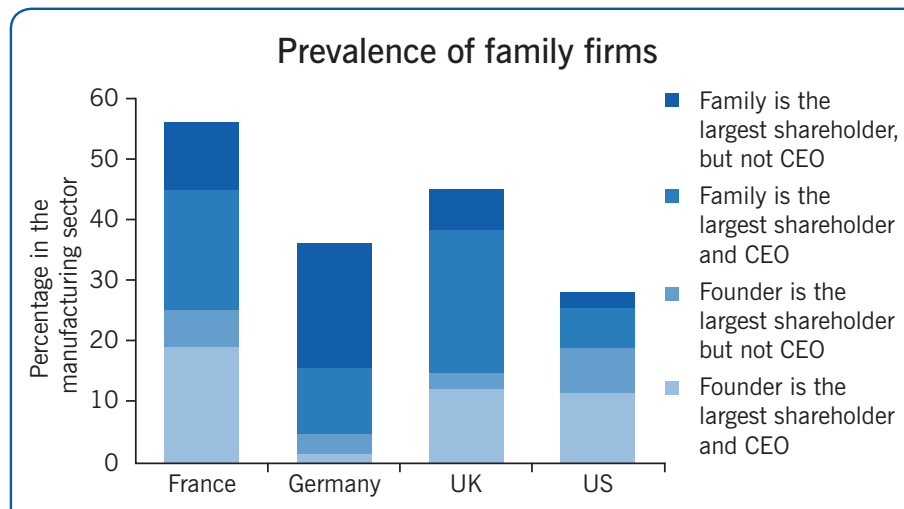

Source: Based on [1], Table 4: only includes firms with between 50 and 10,000 workers.

\section{Cons}

- Family firms pay lower wages.

- Management practices are less conducive to performance in firms that are managed by family members, especially when the manager is the founder's eldest son.

- Family CEOs work less than other CEOs, which may suggest that nepotism, rather than meritocracy, determines promotions in family firms.

\section{AUTHOR'S MAIN MESSAGE}

Family firms represent a form of capitalism that has strong implications for workers. Due to their ability to commit to long-term implicit contracts, and possibly also because they derive utility from it, family firms behave in a more "paternalistic" way, protecting their workers more but paying them less. Their management practices and styles are also drastically different than in non-family firms. Policies toward family firms should therefore be motivated by their impact on the workforce at least as much as on their economic or financial performance, which does not seem to strongly differ from that of other firms. 


\section{MOTIVATION}

Firms that are owned to a large extent by a family or a single individual are named "family firms." These can be compared to "non-family," or "widely held" firms, which are owned by many shareholders who each control a small proportion of the firm's shares or voting rights.

Family firms are either managed by the individual(s) who founded them, one (or several) of their descendants, or an external CEO. Transitions from internal to external management often occur when the firm is passed from one generation to the next, with the founder's heirs retaining ownership but delegating management. Such transitions and differences in management within family firms matter for the workforce, as both the abilities and objectives of these different types of managers can differ substantially.

Contrary to the old idea that ownership in modern corporations is mostly dispersed among small shareholders, family firms are still the most common type of company in terms of ownership in both developed and developing countries [1]. Even in the US, which has the smallest number of family firms, they represent about $30 \%$ of all firms [2]. In continental Europe, they represent the majority in most countries. Family firms are also dominant among both listed and non-listed firms. Contrary to another common idea, they are not limited to small-size businesses that mostly employ family members. In fact, they are almost as well represented among large corporations.

Despite their prevalence, there is still limited evidence on the implications of family ownership and management for the workforce. This is all the more striking since a large literature in corporate finance has highlighted several differences between family firms and widely held firms in terms of governance, management, and objectives, which are likely to directly impact the workforce.

\section{DISCUSSION OF PROS AND CONS}

\section{Family firms offer greater job security}

The most documented difference for workers between family and non-family firms is that family firms offer greater job security and lower wages [3], [4], [5], [6], [7], [8].

The greater job security offered by family firms is evidenced in four distinct ways. First, family firms dismiss their workers less. This has been observed with cross-sectional data, controlling for firms' and workers' relevant observable characteristics [3], and with panel data, linking variations in dismissal rates to changes in ownership structure [4]. The difference in dismissal rates tends to be large. For example, it has been estimated to be around 0.15 percentage points per quarter in France, which represents a $28 \%$ gap between family and non-family firms [4]. There are, however, no differences in other types of separations, such as voluntary quits, between family and non-family firms.

Second, when family firms have to downsize, they tend to do so by reducing hiring more and increasing dismissals less than widely held firms [3], [4]. This suggests that when family firms experience negative shocks that require reductions in employment, they are more concerned about preserving current jobs at the expense of new hires.

Third, studies based on Fortune 500 firms have found that family firms are less likely to downsize than other firms that are performing similarly, especially when managed by 
the family [5]. Family firms are also more likely to smooth out sales and employment variations when hit by an industry-level shock [3], and, as a consequence, their total employment level is less volatile [6].

Finally, family firms are less likely to close than observationally similar non-family firms, at least in non-crisis times [7], which obviously contributes to greater job security.

So, what might explain these differences in terms of job security? A first explanation is that family firms may be more risk averse. Such behavior can be rationalized by the idea that family firms have a preference for survival at the expense of expected profitability. In such a case, they may make less risky investments and, in turn, face more limited economic fluctuations, which gives them a comparative advantage in preserving their workforce. The lower rate of plant closure found in family firms supports this type of interpretation.

However, the fact that family firms also respond differently to industry-level economic fluctuations and that they rely less on layoffs when downsizing suggests that the greater job security in family firms is not just a direct implication of their ability to limit economic fluctuations. Rather, it seems to also be impacted by a differential response to market conditions.

To explain this, scholars rely on the idea that family firms have a comparative advantage in committing to implicit contracts with their workers, that is, to tacit self-enforcing

Figure 1. Layoff rates in family firms before and after transition to external or internal CEOs Layoff rates (all) by transition type

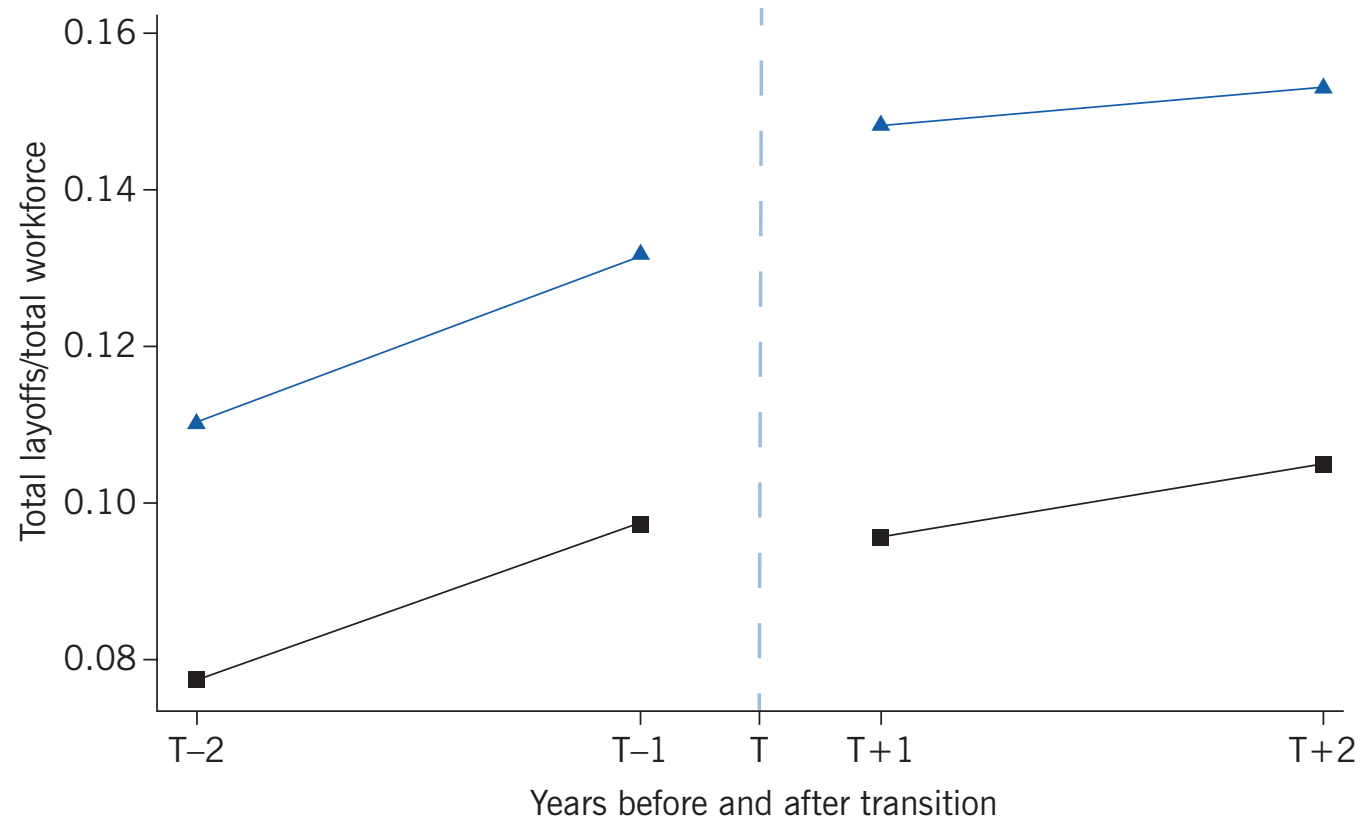

—_ Internal _ External

Note: Layoff rates refer to before and after CEO transitions when the CEO successor is from the same family as the departing CEO (internal) and when it is not (external). The layoff rate is the number of layoffs divided by the total number of employees in a given year. $\mathrm{T}=$ transition year.

Source: Extract from Figure 1 in Bach, L., and N. Serrano-Velarde. "CEO identity and labor contracts: Evidence from CEO transitions." Journal of Corporate Finance 33 (2015): 227-242 [8]. 
contracts that can be credibly sustained in the long term, and that benefit both employees and employers. This comparative advantage may ultimately derive from the fact that family firms adopt longer time horizons as they derive direct utility from the survival of the firm and its transmission across generations. The higher survival rate of family firms, their better resistance to takeovers, and their lower probability to change ownership and management give them credibility to engage ex ante in long-term implicit contracts. This is because workers have some guarantee that the contract will not be breached by an unexpected change in ownership or CEO. This theory is best evidenced by the fact that when external managers are appointed in family firms, layoff rates increase, whereas this is not the case when management of family firms is transmitted within the family (Figure 1) [8]. This suggests that "CEOs promoted from within the family are bound by the employment promises of their predecessors and can credibly engage into new long term contracts" [8]. There is also evidence that the extent of job security offered by family firms is larger when the need for job security on the workers' side is greater (see below), whereas job security in non-family firms does not vary with workers' demands. This also supports the idea that family firms have a comparative advantage in offering job security, and that they exploit this advantage when there is a demand for it.

\section{Family firms pay lower wages}

Regarding wages, evidence is mostly available for France and indicates an average wage gap of about $20 \%$ between non-family and family firms. However, this is largely due to observational differences between both the two types of firms and their workers, such as firm size, industry type, and workers' education. Once those differences are accounted for, family firms pay their employees on average 3\% to $5 \%$ less than their non-family counterparts [3], [4]. A wage gain (drop) of a similar magnitude is observed when a firm evolves from family to non-family (non-family to family) ownership relative to firms that do not change ownership. Furthermore, workers tend to sort across firms when a change in ownership type occurs, with relatively highly paid workers leaving widely held firms that become family firms, and relatively low-paid workers leaving family firms that become widely held. Such sorting is likely to explain the large cross-sectional difference in average wages between family and non-family firms [4].

Finally, there is also some international evidence that family firms offer lower wages, and also that they adjust wages more to economic shocks [6], in contrast to what they do with employment.

The lower wages in family firms may be explained by their higher risk aversion or different management practices, as will be discussed below. Those features may lower their productivity (even if evidence on this point is not fully convergent) and, in turn, force them to pay lower wages in order to survive. However, from the workers' point of view, the lower wages may be acceptable as they are directly compensated for by greater job security [4]. This implies that family firms may have a direct interest in offering lower wages: it will help ensure their survival, which in turn allows them to credibly offer more job security. In that sense, it is not clear whether family firms offer lower wages because they are forced to do so or because they are taking advantage of the situation. 
More generally, job security and wages represent two key differences between the "compensation packages" offered by family and non-family firms. These features seem to go hand in hand and should probably be considered jointly to understand how they can be sustained in both types of firms in the long term.

\section{Management practices}

Research using survey data has shown that management practices differ strongly across firms and that some practices are strongly associated with firm-level productivity, profitability, growth, and survival [2]. Productivity-enhancing management practices typically include the use of lean management techniques, such as just-in-time, to monitor performance, set targets, provide incentives to workers, and attract and retain talented workers, or dismiss poor performers. These practices can be aggregated in a management score that summarizes the quality of management practices in a given firm.

The distributions of management scores across family firms managed by an external CEO and across non-family firms look very similar. However, family firms managed internally by a family member exhibit worse management practices. In particular, firms who have passed management control down to the eldest sons according to the traditional principle of primogeniture have the least productivity-enhancing practices. This may be explained by the fact that primogeniture prevents firms from selecting their CEO from a large pool of talented individuals. Primogeniture may also reduce human capital investment by heirs, who know that they will eventually be offered the opportunity to manage the firm no matter their initial level of effort [2]. Family firms managed by their founder also tend to have less productivity-enhancing management practices, which may be due to the fact that the skills required to start up a business (e.g. creativity and risk-taking) are not the same as those needed to manage a mature firm.

Given the above evidence, why don't family firms' owners anticipate these issues and decide more often to hire external CEOs? One possible explanation is that they have biased beliefs about their ability or the ability of their descendants to run the firm. Another, perhaps more obvious, reason is that family members receive amenity value from managing the firm that has made the family famous for generations and from pursuing the family tradition that the eldest son take over the management. This private utility derived from managing the firm rather than doing another job-or not workingmay explain why family firms' owners are inclined to retain a management role instead of delegating it to external individuals that may be better suited for the job.

This latter explanation is also compatible with the idea that the management practices of family firms are a matter of culture rather than skills. In other words, if family members run the firm in a manner that is perceived as suboptimal, it is not necessarily because they do not have the skills to do better. It may be that they also derive direct amenities from being paternalistic with their employees and thus actively choose to operate differently. In other words, if family firms have different (or additional) objectives than that of maximizing firm value, then their management practices may actually be well suited to reaching their objectives. 


\section{Dealing with hostile labor relations}

It has been argued that family firms are more effective at coping with labor relations that are more hostile and confrontational (and less collaborative) [9]. This theory is supported by a series of empirical results [9], [10]. First, there are more family firms in countries where employment relations are described by managers as being less cooperative (Figure 2). Second, family firms are also more prevalent in countries that developed hostile labor relations for historical reasons unrelated to family ownership, suggesting that family firms indeed have a comparative advantage to deal with such hostile labor relations. Third, in countries with hostile labor relations, industries that rely heavily on labor have relatively more family firms than other industries, suggesting that the negative correlation between the extent of family capitalism in a country and the quality of its labor relations is not due to omitted country characteristics. Fourth, controlling for firm age, number of employees, and industry, it is found that unionization rates are about $30 \%$ lower in family firms. Fifth, conditional on firm size, labor conflicts are less intense and less frequent in family firms, and this is equally true in all family firms, independent of them being managed internally or by an external CEO, or of them being controlled by the founder or their descendants [10].

Two main proximate factors can explain the comparative advantage of family firms to deal with hostile employment relations [9]. First, the greater job security offered by family firms and more generally the implicit contracts they are able to offer to their workers may

Figure 2. Family ownership and countries' extent of labor cooperation

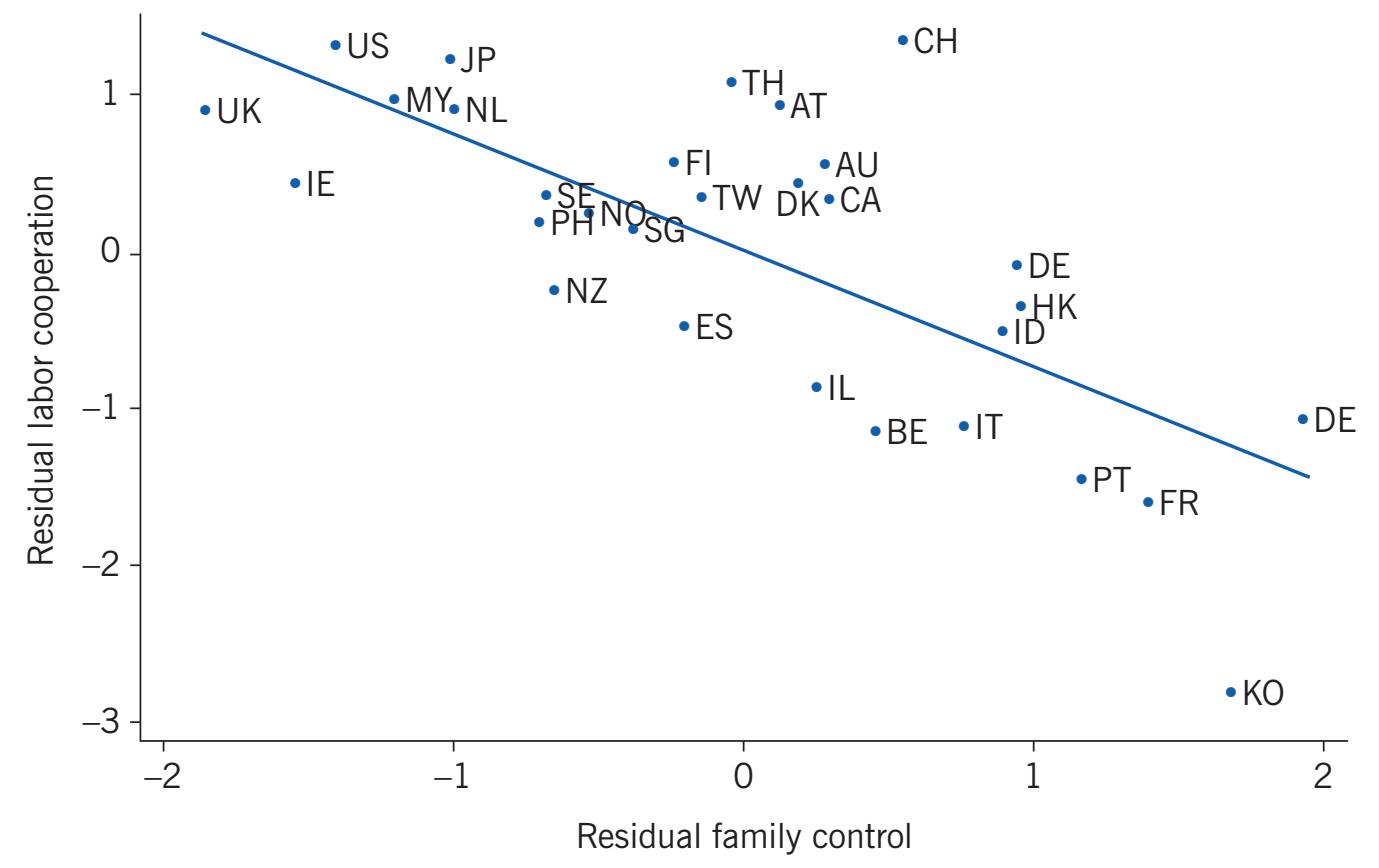

Note: The figure shows that there are more family firms in countries where labor cooperation is lower. Residuals are from regressions of measures of labor cooperation and family control on each country's population and GDP per capita, which are also interacted with the fact of being an Asian country.

Source: Mueller, H. M., and T. Philippon. Family Firms, Paternalism, and Labor Relations. NBER Working Paper No. 12739, December 2006. 
be reciprocated by more cooperation on the worker's side, implying better employment relations. Second, the attachment of family owners or CEOs to their firm implies that they may be willing to do more than external managers to defend the firm's interests in case of conflict with workers. The fear of potentially tough reactions by managers would in turn tame family firms' workers' claims, limiting the extent of open conflicts. Yet another explanation could be that family firms have a greater ability to develop management styles that prevent labor conflicts. Family capitalism is indeed often associated with what is referred to as a "paternalistic" management style, the name given by some historians to a type of labor management that developed at the end of the 19th century to cope with the increase in labor conflicts at that time. When workers started organizing collectively to defend their rights and working conditions, they initially faced strong repression from employers. However, repressive strategies were not always sufficient to discourage labor conflict, and some employers developed an alternative strategy that partly involved making management much more inclusive. For example, some firms offered various forms of social protection or fringe benefits to workers, or shared some profits with them. These employers were acting with their workers as fathers might do at home with their children. This type of management may have made workers naturally more obedient, as bargaining or protesting would be seen as a lack of respect toward the paternalist figure of the employer. As such, paternalism may be seen as a way of dealing with the historical increase in workers' claims for improved rights and remuneration. Family firms managed by a member of the family are obviously better placed to develop this management style, as the comparison of the firm with a family figure is not only symbolic but also real. In that sense, family firms may have a comparative advantage at developing a paternalistic management style that seems better suited to cope with hostile employment relations.

A common issue among the above-mentioned explanations for better labor relations among family firms is that they are more likely to hold in family firms that are managed by their founder or another family member, and should therefore imply even fewer labor conflicts in this subgroup. However, this is not the case empirically, at least not in France [10]. Additional research is thus necessary to identify more precisely what drives family firms' ability to better cope with hostile employment relations.

Finally, the specificities of family firms in terms of job security, wages, and management practices may also be reconsidered from the angle of paternalism, broadly considered as a management style designed to foster cooperation from workers and limit conflict. This is because those aspects may be considered as particular features of such a management style. For example, providing greater job security to workers may engage them in a longerterm relationship with their employer, which in turn dissuades them from starting labor conflicts. The idea that family firms have "worse" management practices should also be considered with caution, as management practices considered to be inferior for firms' economic performance may actually help them to deal with hostile employment relations and may have positive consequences for the workforce. For example, some of the productivity-enhancing practices involve attracting and retaining talented workers while dismissing those who are not well suited for the job quickly. It is intuitive that such practices can have positive effects on productivity. However, it seems difficult to apply those management rules while at the same time offering greater job security and committing to long-term implicit contracts. 


\section{A substitute for public employment insurance and labor market regulation on firing}

Another possible implication of the greater ability of family firms to offer long-term implicit contracts is that they can act as a substitute for other forms of insurance to labor market shocks, such as those provided by governments or social partners. If family firms and public regulation can both provide insurance to workers, the former may have a comparative advantage in countries where the latter is less developed, and vice versa.

Those interactions between country-level regulation and individual governance structures are tested in two recent working papers [6], [10]. The first shows that the difference between family and non-family firms in terms of employment stability and wages is greater in countries where public unemployment insurance is less generous [6]. This result is consistent with the idea that family firms have a comparative advantage at offering greater job stability to their workers and that they will do so to a larger extent when the demand for job stability is high, which is the case in the absence of a good public unemployment insurance system.

Another paper studies the interaction between labor market regulation on firing and family firms [11]. Labor market regulation on firing is arguably a public form of employment protection, which can also act as a substitute for the employment insurance provided by family firms due to the greater job stability they are able to offer. This idea is supported by the fact that family firms experience lower variations in employment levels in countries with less regulated labor markets, hence providing more direct insurance when public insurance is less available. Family firms also perform better than their non-family counterparts in these countries, suggesting that they are able to push their comparative advantage at offering greater job security and to turn it into actual economic gains in countries where alternative forms of employment insurance are less available.

\section{Workers' reactions to the way family firms treat them}

Family and non-family firms provide their workers with different compensation schemes and manage them differently, clearly implying that working in the two types of firm is not equivalent. A natural research agenda is then to understand how workers respond to these differences. However, there is only limited evidence on this matter. That which does exist shows that workers sort between both types of firms according to their ability [4]. This sorting may actually hide a sorting based on preferences, with more-able workers also being more career-oriented and having a relative preference for wages over job security, but this still needs to be proven for rank-and-file workers. Such sorting on preferences would be rational and mimic the differences in preferences observed among CEOs, with family CEOs being more leisure-oriented than non-family ones [12].

Workers in family firms have also been shown to have absenteeism rates $14 \%$ lower than in non-family firms [13]. Only one-fourth of this differential can be explained by the sorting of workers across types of firms. The remaining difference, a gap of about $10 \%$, can be interpreted as a differential reaction of similar workers to their working environment. An obvious interpretation of this result is that working in a family firm implies a lower likelihood of being sick or injured. This interpretation has been convincingly rejected. 
Instead, the differential in absences is likely to reflect differences in motivation and effort, which may be explained by two already mentioned features of family firms: the greater ability or willingness of family managers to monitor or be tough with their workforce, and the fact that workers may respond to the implicit contract offered with higher cooperation and loyalty. Those higher effort levels observed in family firms are, however, at odds with the very common idea that incentives in those firms are muted for workers who are not members of the family because of nepotism. If top management positions are reserved for family members, other workers that are high enough in the hierarchy to apply for those positions have a lower probability of being promoted and should thus be less incentivized to exert high levels of effort. There are indications that such a mechanism might be at play as the absence differential between non-family and family firms becomes close to zero among senior managers.

\section{LIMITATIONS AND GAPS}

Research on the implications of family firms for the workforce is still fairly recent. Some results have already been well established but there are still a number of gaps.

One gap that could be filled rather easily concerns the careers of various types of workers in family and non-family firms. The widespread idea that career prospects are worse in family firms for non-family members because managers are entrenched has never been tested directly. Panel data allowing researchers to follow workers in family and nonfamily firms is now available in a number of countries; it would be useful to document the promotion rates and career paths over a large number of years of various categories of similar workers in both types of firms.

The actual behavior of family members in family firms also deserves further investigation, as it seems that family CEOs work less than non-family CEOs [12], but that, within family firms, other family members exert higher effort levels than other employees [13]. One explanation could be that family members who are not yet CEOs are still competing for top management positions and thus exert higher effort.

Other limitations concern differences in management practices and styles, and their normative implications. Practices that are widespread in family firms and related to lower productivity may often be considered as part of their "paternalist management" style, which also seems to offer a number of comparative advantages with respect to the workforce. For example, family firms seem less likely to incentivize workers by linking compensation to performance (one of the good practices mentioned in [2]), but they nevertheless seem to obtain higher levels of effort from their workers [13]. Such a result shows that paternalism is very difficult to fully characterize, and that its normative implications are complex and hard to assess.

\section{SUMMARY AND POLICY ADVICE}

One result stands out as being well established when it comes to family firms: they are able to offer greater job security to their workers, but pay them lower wages than nonfamily firms do. Research also shows that family firms have a different management style, which workers respond to in various ways, and that they can act as substitutes for some types of public regulations. 
Altogether, the literature draws a rather complex portrait of what it is to work in family firms, with many gaps yet to be filled. It calls for cautiousness when discussing policy toward family firms. For example, many European countries exempt family business assets from inheritance and wealth tax bases, even though such assets are disproportionately held by wealthy households. To investigate if such tax policies could be economically justified, a number of papers in corporate finance have focused on performance differences between family and non-family firms, especially when family firms are transmitted across generations. Even if the debate is still ongoing, research tends to find that family firms owned and managed by descendants of their founders perform equally or worse than their non-family counterparts, showing that tax exemption cannot be directly justified by a better economic performance of inherited family firms. However, the transmission of management across generations is likely to be one of the key features allowing family firms to credibly commit to long-term implicit contracts with their workers and to guarantee that they will not be fired in the future after a change in management has occurred. Hence, limiting the scope for the transmission of family firms across generations may also have unexpected consequences for the workforce.

Policies toward family firms may also differ across countries since those firms may act as substitutes for some forms of otherwise publicly provided insurance. Overall, the existing evidence calls for a more careful consideration of the implications of family capitalism for employees in policy making, as these firms can provide a type of compensation that others cannot, and which can be desirable for at least some workers, especially in more unregulated labor markets.

\section{Acknowledgments}

The author thanks two anonymous referees and the IZA World of Labor editors for many helpful suggestions on an earlier draft. Previous work of the author (together with Andrea Bassanini, Eve Caroli, and Antoine Rebérioux) contains a larger number of background references for the material presented here and has been used intensively [4].

\section{Competing interests}

The IZA World of Labor project is committed to the IZA Guiding Principles of Research Integrity. The author declares to have observed these principles.

(c) Thomas Breda 


\section{REFERENCES}

\section{Further reading}

Adams, R. B., M. Keloharju, and S. Knüpfer. Are CEOs Born Leaders? Lessons from Traits of a Million Individuals. Harvard Business School Research Paper No. 16-044, October 2015.

Stavrou, E., G. Kassinis, and A. Filotheou. "Downsizing and stakeholder orientation among the Fortune 500: Does family ownership matter?” Journal of Business Ethics 72:2 (2007): 149-162.

\section{Key references}

[1] Faccio, M., and L. H. P. Lang. "The ultimate ownership of Western European corporations." Journal of Financial Economics 65:3 (2002): 365-395.

[2] Bloom, N., and J. Van Reenen. "Measuring and explaining management practices across firms and countries." The Quarterly Journal of Economics 122:4 (2007): 1351-1408.

[3] Sraer, D., and D. Thesmar. "Performance and behavior of family firms: Evidence from the French stock market." Journal of the European Economic Association 5:4 (2007): 709-751.

[4] Bassanini, A., T. Breda, E. Caroli, and A. Rebérioux. "Working in family firms: Paid less but more secure? Evidence from French matched employer-employee data." ILR Review 66:2 (2013): 433466.

[5] Block, J. "Family management, family ownership, and downsizing: Evidence from S\&P 500 firms." Family Business Review 23:2 (2010): 109-130.

[6] Ellul, A., M. Pagano, and F. Schivardi. "Employment and wage insurance within firms: Worldwide evidence." The Review of Financial Studies 104 (2017).

[7] Bryson, A., H. Dale-Olsen, and T. Gulbrandsen. Family Ownership, Workplace Closure and the Recession. IZA Discussion Paper No. 9877, April 2016.

[8] Bach, L., and N. Serrano-Velarde. "CEO identity and labor contracts: Evidence from CEO transitions." Journal of Corporate Finance 33 (2015): 227-242.

[9] Mueller, H. M., and T. Philippon. "Family firms and labor relations." American Economic Journal: Macroeconomics 3:2 (2011): 218-245.

[10] Belot, F., and T. Waxin. "Labor conflicts in French workplaces: Does (the type of) family control matter?" Journal of Business Ethics 146:3 (2017): 591-617.

[11] Bennedsen, M., S. Huang, H. F. Wagner, and S. Zeume. Family Firms and Labor Market Regulation. INSEAD Working Paper No. 2014/62/EPS, September 2015.

[12] Bandiera, O., R. Lemos, A. Prat, and R. Sadun. Managing the Family Firm: Evidence from CEOs at Work. NBER Working Paper No. 19722, December 2013.

[13] Bennedsen, M., M. Tsoutsoura, and D. Wolfenzon. Ownership Structure and Employee Effort: Evidence from Family Firms. Working Paper, September 2016.

\section{Online extras}

The full reference list for this article is available from:

https://wol.iza.org/articles/working-in-family-firms

View the evidence map for this article:

https://wol.iza.org/articles/working-in-family-firms/map 